\title{
PEMANFAATAN KOLAM RETENSI DAN SUMUR RESAPAN PADA SISTEM DRAINASE KAWASAN PADAT PENDUDUK
}

\author{
Doddy Yudianto, Andreas F. V. Roy \\ Staff Pengajar, Jurusan Teknik Sipil, Fakultas Teknik \\ Universitas Katolik Parahyangan, Jl. Ciumbuleuit 94, Bandung, 40141 \\ e-mail: doddi_yd@unpar.ac.id; andrevan@home.unpar.ac.id
}

\begin{abstract}
Change of land use in high population density area, especially enlargement of impervious area, will give direct impact to the increasing of runoff volume which at the end may result increasing of flood risk. One of the solutions to reduce the flood risk is by applying sustainable drainage system. In the western part of Bandung City where an area of 1.5 hectare was planned to be developed as $100 \%$ of impervious area for supporting the manufacture storage purposes complete with the whole related infrastructures. In the mean time, the surface runoff at that particular area is drained into $0.2 \mathrm{~m}$ x $0.2 \mathrm{~m}$ of rectangular channels with an outlet point at the surrounding residential drainage system. By developing the whole area to be impervious, the analysis result shows that the existing channels are not capable to properly drain the runoff. The channels need to be enlarged to be $0.5 \mathrm{~m} \mathrm{x} 0.4 \mathrm{~m}$ at the upstream part and $0.5 \mathrm{~m} \times 0.7 \mathrm{~m}$ at the downstream part. To provide sustainable drainage, the system is designed by combinating the application of retention pond and recharging well. The analysis result shows that the application of $7.0 \mathrm{~m}$ x $20.0 \mathrm{~m}$ x $1.5 \mathrm{~m}$ of retention pond and recharging well of 1.25 of diameter with $10 \mathrm{~m}$ of depth could store 10 years period of flood and recharge the groundwater at 10 $\mathrm{m}$ of depth of aquifer at rate of $0.007 \mathrm{~m} 3 / \mathrm{s}$.
\end{abstract}

Keywords: Sustainable drainage system, Retention pond, Recharging well.

\begin{abstract}
ABSTRAK
Perubahan tata guna lahan pada kawasan padat penduduk berupa peningkatan luas area kedap air akan memberikan dampak langsung pada peningkatan volume limpasan. Kondisi peningkatan volume limpasan ini berjalan seiring dengan peningkatan resiko terjadinya banjir pada kawasan tersebut. Salah satu upaya mengurangi resiko terjadinya banjir pada kawasan tersebut adalah dengan menerapkan konsep sistem drainase berkelanjutan. Sebuah lahan seluas 1,5 hektar yang terletak di kawasan padat penduduk di sisi barat Kota Bandung direncanakan akan dikembangkan seluruhnya menjadi area pergudangan lengkap dengan prasarananya. Saat ini limpasan air hujan yang terjadi dilayani oleh saluran drainase berdimensi 0,2 $\mathrm{m}$ x 0,2 $\mathrm{m}$ dengan titik keluaran pada saluran drainase kawasan permukiman sekitar. Dengan dikembangkannya seluruh lahan menjadi lapisan kedap air, hasil analisis menunjukkan bahwa saluran yang ada tidak mampu untuk menampung volume limpasan yang terjadi. Dimensi saluran drainase perlu diperbesar menjadi $0,5 \mathrm{~m}$ x $0,4 \mathrm{~m}$ pada bagian hulu dan $0,5 \mathrm{~m} \times 0,7 \mathrm{~m}$ pada bagian hilir sistem drainase. Upaya penerapan konsep sistem drainase berkelanjutan dilakukan dengan merencanakan pemanfaatan kolam retensi dikombinasikan dengan aplikasi sumur resapan. Hasil analisis menunjukkan bahwa kombinasi pemanfaatan kolam retensi dengan dimensi 7,0m x 20,0m x 1,5m dan sumur resapan dengan dimensi jari-jari 1,25m dan kedalaman 10,0m dapat menampung volume limpasan dengan periode ulang debit banjir 10 tahun. Sistem ini sekaligus meresapkan kembali air ke dalam lapisan akuifer pada kedalaman 10 m dengan debit sebesar 0,007 $\mathrm{m}^{3} / \mathrm{dt}$.
\end{abstract}

Kata kunci: Sistem drainase berkelanjutan, Kolam Retensi, Sumur Resapan. 


\section{PENDAHULUAN}

Perubahan tata guna lahan sebuah kawasan akan menyebabkan terjadinya perubahan volume limpasan air hujan pada kawasan tersebut. Peningkatan volume limpasan umumnya terjadi sebagai akibat dari bertambahnya luasnya lapisan kedap air pada kawasan tersebut. Tanpa penanganan mitigasi yang memadai, fenomena peningkatan volume limpasan akan berakibat pada peningkatan resiko terjadinya genangan atau banjir pada kawasan tersebut. Kondisi menjadi semakin memburuk jika kapasitas saluran drainase yang telah ada ternyata tidak lagi mencukupi.

Sistem drainase perkotaan berkelanjutan merupakan konsep yang sepatutnya diterapkan pada proses pengembangan kawasan padat penduduk. Limpasan yang terjadi pada musim hujan pada suatu kawasan diupayakan untuk dapat dikendalikan dan dimanfaatkan kembali seoptimum mungkin termasuk upaya peresapan kembali ke dalam tanah.

Makalah ini akan membahas mengenai pemanfaatan kolam retensi yang difungsikan secara kombinasi dengan sumur resapan dalam upaya menerapakan konsep sistem drainase berkelanjutan. Dalam studi ini dipilih sebuah lahan seluas 1,5 hektar yang terletak pada kawasan padat penduduk di sisi barat Kota Bandung yang direncanakan akan dikembangkan sebagai area pergudangan yang kedap air lengkap beserta prasarananya.

\section{PEMBANGUNAN BERKELANJUTAN DAN SISTEM DRAINASE BERKELANJUTAN}

Isu sistem drainase berkelanjutan adalah merupakan bagian kecil dari isu besar pembangunan berkelanjutan. Isu ini merupakan isu hangat yang belakangan menjadi semakin bergema sejak dicetuskannya The Earth Summit di Rio de Janeiro, Brazil pada tanggal 3-14 Juni 1992. Pada pertemuan tersebut dihasilkan 27 buah prinsip dimana prinsip ke-empat menyatakan bahwa kegiatan pembangunan harus melibatkan sekaligus upaya pelestarian lingkungan.

Pertumbuhan jumlah penduduk dan peningkatan aktivitas ekonomi dan sosial di daerah perkotaan telah memicu kegiatan pembangunan berupa penyediaan prasarana dan sarana penunjang kegiatan sosial ekonomi dengan cepat. Kondisi ini serta merta telah mendorong terjadinya perubahan tata guna lahan secara pesat pula. Namun demikian pembangunan yang dilakukan perlu tetap mempertimbangkan kelestarian dan keserasian lingkungan beserta keseimbangan pemanfaatan sumberdaya yang ada termasuk daya dukungnya sejak tahap perencanaan, pengelolaan dan pengembangan. 
Dari sudut pengelolaan sumber daya air, tekanan yang dihasilkan akibat perubahan tata guna lahan pada daerah perkotaan umumnya berupa peningkatan volume limpasan serta penurunan tingkat resapan air. Kondisi ini lebih jauh dapat memicu terjadinya ketimpangan distribusi air antara musim kemarau dan musim hujan. Fakta menunjukan bahwa pada beberapa tahun terakhir ini telah terjadi fenomena kekeringan pada saat musim kemarau sementara pada musim hujan bencana banjir tetap saja terjadi [Suripin, 2004].

Menurut Suripin, pengelolaan limpasan permukaan merupakan prioritas kegiatan utama yang harus dilakukan dalam proses pengembangan suatu kawasan. Pengelolaan limpasan yang ditujukan untuk meminimalkan tingkat kerugian serta upaya konservasi lingkungan dengan meningkatkan daya guna air termasuk peningkatan tingkat resapan air merupakan prinsip-prinsip dari sistem drainase berkelanjutan.

Istilah sistem drainase berkelanjutan belum memiliki istilah umum yang disepakati bersama. Di Inggris sistem ini dikenal dengan nama sustainable urban drainage system (SUDS), sementara pendekatan pengelolaan air hujan ini di Amerika dikenal dan dikategorikan dalam low impact development (LID) atau best management practise (BMP). Di Australia dikenal dengan water sensitive urban design (WUDS) dan beberapa negara maju lain menamakannya integrated catchment planning dan ecological stormwater management [Andah dan Iwugo, 2002; Stahre 2005; Spillett dan rekan, 2005; DTI Global Watch Mission, 2006]

Di negara maju aplikasi sistem drainase berkelanjutan yang telah dilakukan meliputi berbagai teknik. Sebagai contoh, dimanfaatkannya materi porous dalam menutup permukaan seperti lahan parkir, jalan lingkungan, dan lain-lain. Contoh lainnya adalah pembangunan kolam penampung yang dikombinasikan dengan wet land pada sejumlah area tertentu. Namun pada dasarnya prinsip utama dari berbagai pendekatan teknis tersebut tidak lain adalah merencanakan sistem drainase seoptimum mungkin agar mendekati kondisi sistem drainase natural.

Beberapa keuntungan yang akan didapat dalam upaya penerapan sistem drainase berkelanjutan meliputi:

1. Secara tidak langsung berpotensi menurunkan biaya pengembangan wilayah,

2. Dapat menurunkan tingkat polusi sehingga terjadi perbaikan kualitas lingkungan,

3. Memperbaiki metoda perancangan penanganan limpasan permukaan,

4. Menurunkan resiko terjadinya banjir, dan

5. Mengisi kembali air tanah dalam tingkat lokal.

Pemanfaatan Kolam Retensi Dan Sumur Resapan Pada Sistem Drainase Kawasan Padat Penduduk (Doddy Yudianto, Andreas F. V. Roy) 


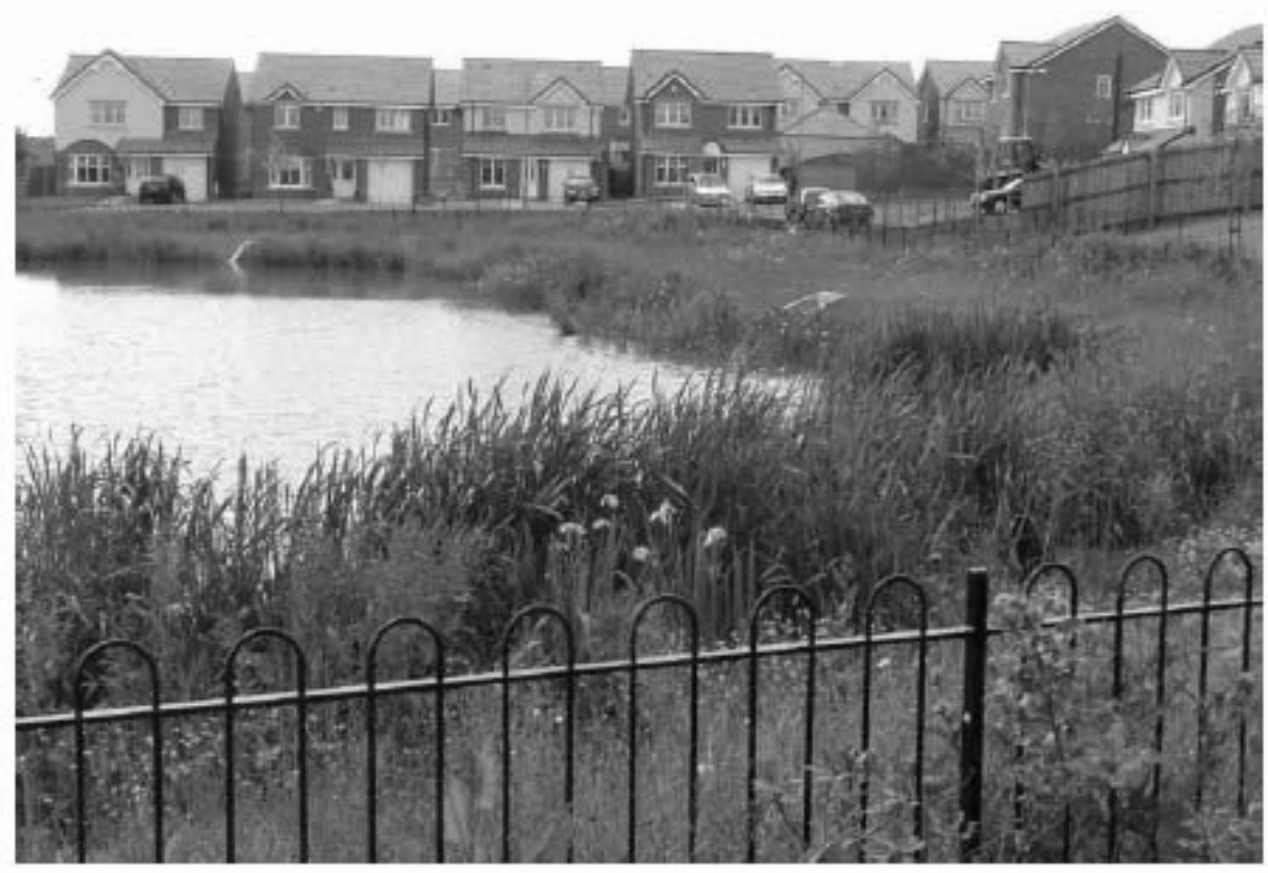

Gambar 1. Gambar kolam penampung dan wet land.

(http://www.scotland.gov.uk/Publications/2009/01/27140909/10)

Namun demikian di samping potensi keuntungan dengan diterapkannya sistem drainase berkelanjutan, terdapat beberapa aspek yang dapat menghambat penerapan dan pengembangan sistem ini. Aspek legal, aspek kepemilikan, aspek pembiayaan, aspek pemeliharaan serta aspek administratif dan kelembagaan merupakan aspek-aspek yang harus dipikirkan dengan matang. Andah dan Iwugo, 2002, Stahre 2005 serta Spillett dan rekan, 2005, mendapati bahwa aspek-aspek tersebut seringkali menjadi aspek penyebab gagalnya sistem beroperasi secara berkelanjutan, disamping pula menjadi penghambat implementasi serta pengembangan sistem ini ketika jumlah pihak yang terkait dan berkepentingan menjadi banyak.

\section{KOLAM TAMPUNGAN DAN SUMUR RESAPAN}

Secara nyata pengelolaan limpasan permukaan dilakukan dengan mengembangkan fasilitas pengendali atau penahan limpasan. Berdasarkan fungsinya, fasilitas pengendali atau penahan limpasan dapat dikelompokkan atas dua jenis, yaitu jenis penyimpan (storage types) dan jenis peresapan (infiltration types). Jenis penyimpan berdasarkan lokasinya dapat dibedakan atas penyimpanan di luar lokasi (off-site storage) dan penyimpan di dalam lokasi 
(on-site storage). Penyimpan jenis on-site storage digunakan jika air hujan yang jatuh di kawasan sendiri tidak dibuang ke saluran luar sebagai akibat ketidakmampuan atau adanya keragu-raguan terhadap kinerja saluran luar. Fasilitas seperti kolam tampungan atau kolam parkir banjir (retarding pond) dan kolam regulasi (regulation pond) merupakan contohcontoh dari storage types [Suripin, 2004].

Pemanfaatan jenis resapan (infiltration types) digunakan pada daerah yang memiliki tingkat permeabilitas tinggi dan secara teknik pengisian air tanah tidak mengganggu stabilitas geologi. Parit resapan, sumur resapan, kolam resapan serta perkerasan resapan merupakan contoh dari fasilitas jenis resapan. Prinsip jenis resapan adalah untuk mengurangi air permukaan (run off) dan memperlama waktu tinggal air di dalam tanah, sehingga jumlah air yang melimpah dan risiko banjir berkurang serta sekaligus meningkatkan ketersediaan air tanah.

Beberapa faktor yang mempengaruhi dimensi kolam tampungan dan sumur resapan untuk suatu lahan sangat bergantung pada beberapa faktor [Suripin, 2004]:

1. Luas permukaan penutupan, yaitu lahan yang limpasannya akan ditampung dalam kolam atau sumur resapan.

2. Karakteristik hujan, meliputi intensitas hujan, lama hujan, dan selang waktu hujan. Secara umum dapat dikatakan bahwa makin tinggi hujan, makin lama berlangsungnya hujan sehingga memerlukan volume tampungan yang makin besar. Sementara selang waktu hujan yang besar dapat mengurangi ukuran volume sumur yang diperlukan.

3. Permeabilitas tanah, yaitu kemampuan tanah untuk melewatkan air persatuan waktu. Tanah berpasir memiliki permeabilitas yang lebih tinggi dibandingkan tanah lempung.

4. Tinggi muka air tanah. Pada dasarnya untuk kondisi lahan dimana muka air tanah adalah dangkal, pembuatan sumur resapan dangkal kurang efektif atau dengan kata lain guna meresapkan air perlu dibuat sumur resapan dalam.

Adapun persyaratan umum yang perlu diperhatikan dalam perencanaan sumur resapan antara lain [Suripin, 2004]:

1. Sumur resapan air hujan dibuat pada lahan yang memiliki permeabilitas tinggi, atau memiliki lapisan akuifer yang cukup tebal.

2. Sumur resapan hujan harus bebas kontaminasi limbah. Dengan kata lain, air yang diperbolehkan untuk diresapkan hanyalah air hujan.

3. Untuk daerah sanitasi lingkungan buruk, sumur resapan air hujan hanya menampung air dari atap dan disalurkan melalui talang.

4. Dalam perencanaan perlu dipertimbangkan aspek hidrogeologi, geologi, dan hidrologi. 
5. Terpenuhinya jarak minimum sumur resapan terhadap bangunan lainnya seperti tersaji pada Tabel 1.

Tabel 1. Jarak minimum sumur resapan terhadap bangunan lain [Suripin, 2004]

\begin{tabular}{lll}
\hline No. & Bangunan yang ada & Jarak minimal dengan sumur \\
\hline 1 & Bangunan/rumah & 3,0 \\
2 & Batas pemilikan lahan & 1,5 \\
3 & Sumur untuk air minum & 10,0 \\
4 & Septik tank & 10,0 \\
5 & Aliran air (sungai) & 30,0 \\
6 & Pipa air minum & 3,0 \\
7 & Jalan umum & 1,5 \\
8 & Pohon besar & 3,0 \\
\hline
\end{tabular}

Pusat Penelitian dan Pengembangan Permukiman, Departemen Pekerjaan Umum (1990) telah menyusun standar tata cara perencanaan teknis sumur resapan air hujan yang dituangkan dalam SK SNI-T-06-1990F. Perencanaan sumur resapan berdasarkan standar PU tersebut dapat digambarkan sesuai dengan diagram alir yang tersaji pada Gambar 2.

\section{GAMBARAN UMUM DAERAH STUDI}

Lokasi studi memiliki luas sebesar 1,5 hektar dengan kondisi saat ini 35\% dari luas total lahan digunakan untuk sebagai area pergudangan. Sementara sisanya masih berupa lahan terbuka yang ditumbuhi oleh rumput-rumput liar. Lokasi daerah studi yang terletak di sisi Barat Kota Bandung ini merupakan kawasan padat penduduk. Di dalam rencana pengembangannya, lahan ini akan digunakan seluruhnya sebagai area pergudangan yang dilengkapi oleh fasilitas jalan lingkungan yang menggunakan perkerasan lentur. Gambar 3 menampilkan peta dan denah kawan dimaksud. Gambar 4 menunjukkan peta rencana pengembangan lahan. 


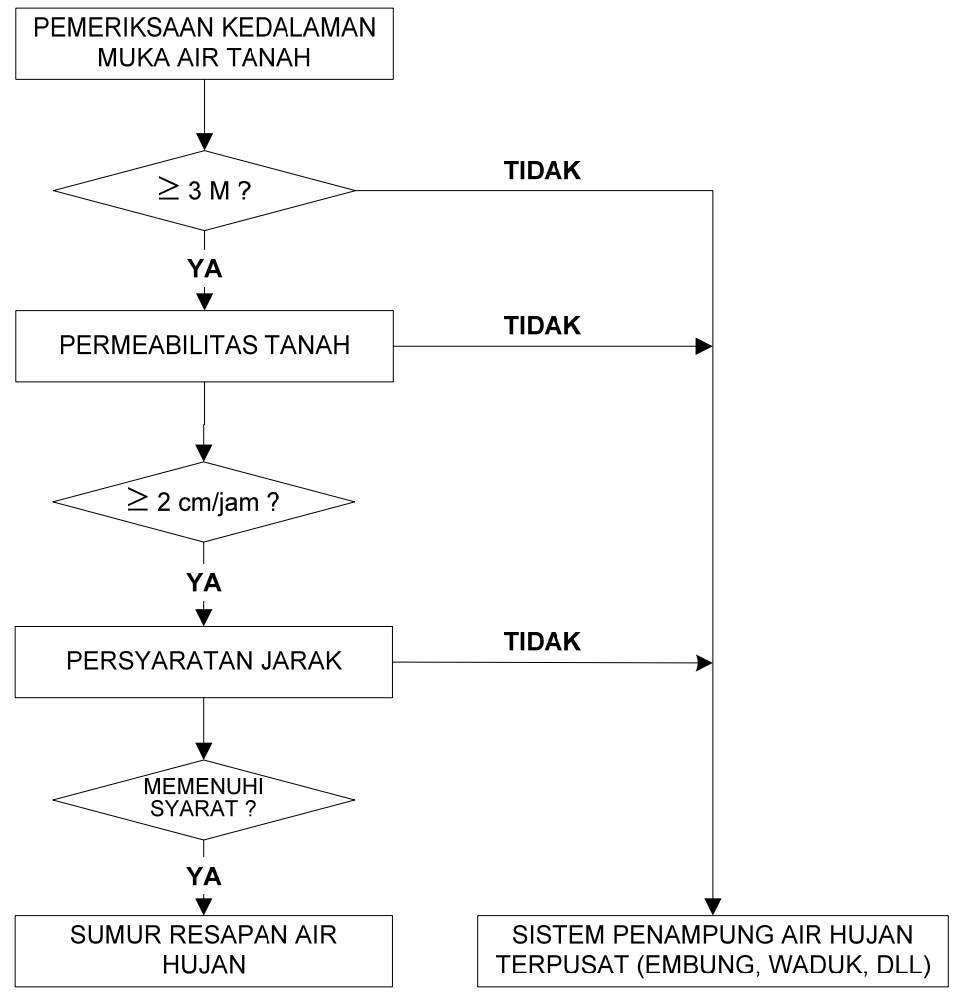

Gambar 2. Diagram alir perencanaan sumur resapan [Suripin 2004].

Berdasarkan hasil survei lapangan yang dilakukan dapat diketahui bahwa kondisi topografi lahan relatif datar. Sementara pada sisi kiri, kanan dan belakang lahan berbatasan langsung dengan daerah pemukiman padat penduduk. Sistem drainase di dalam area gudang berupa saluran berdimensi 0,2 m x 0,2 m. Sementara sistem drainase sekitar lahan merupakan kombinasi antara saluran limbah rumah tangga dan saluran limpasan air hujan yang berasal dari area gudang maupun lingkungan sekitar.

Dengan kapasitas saluran outlet sistem drainase yang relatif kecil yaitu $0,2 \mathrm{~m} \times 0,2$ $\mathrm{m}$, dapat diperkirakan bahwa setelah seluruh lahan ditutup oleh lapisan kedap air, beban limpasan yang terjadi tidak memungkinkan lagi untuk disalurkan keluar tanpa adanya fasilitas pengendali atau penahan limpasan. Untuk itu dalam upaya penerapan sistem drainase berkelanjutan, dalam tulisan ini dilakukan analisis dan simulasi pemanfaatan kolam retensi banjir beserta aplikasi sumur resapan sebagai upaya alternatif dan preventif dalam melakukan mitigasi atas resiko banjir. 


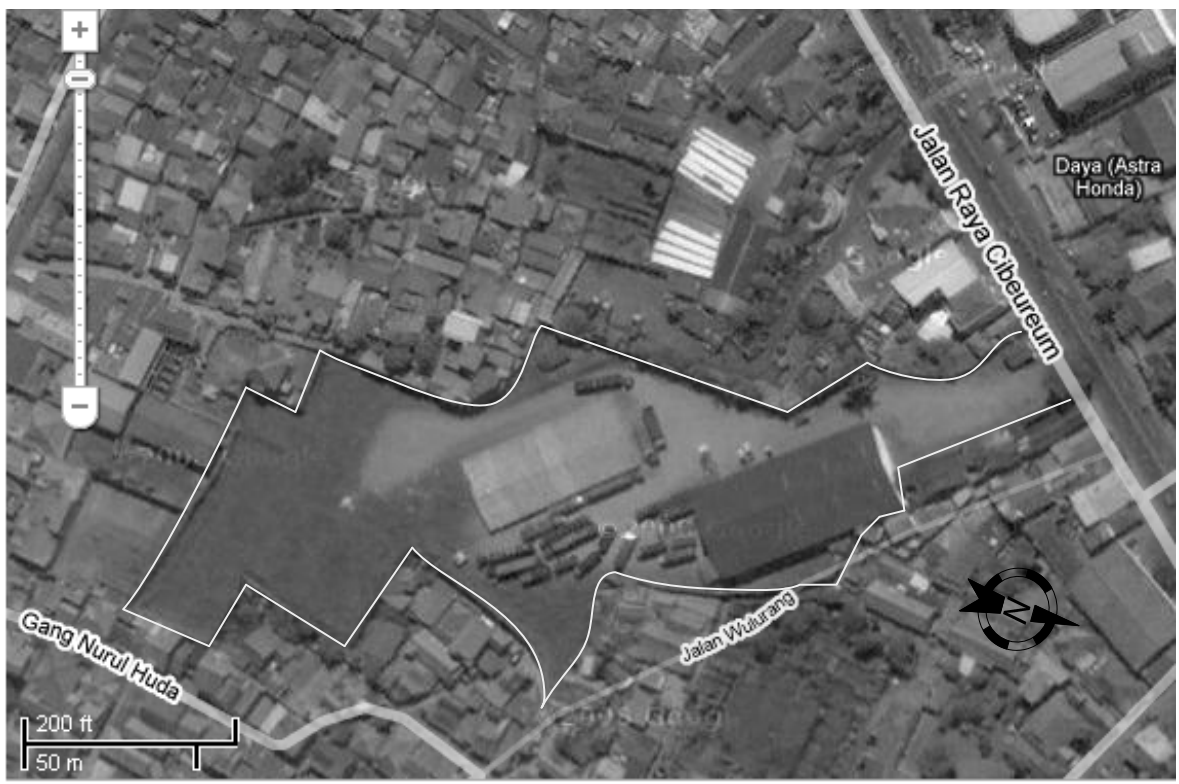

Gambar 3. Peta lokasi dan situasi daerah kajian (http://maps.google.com/).

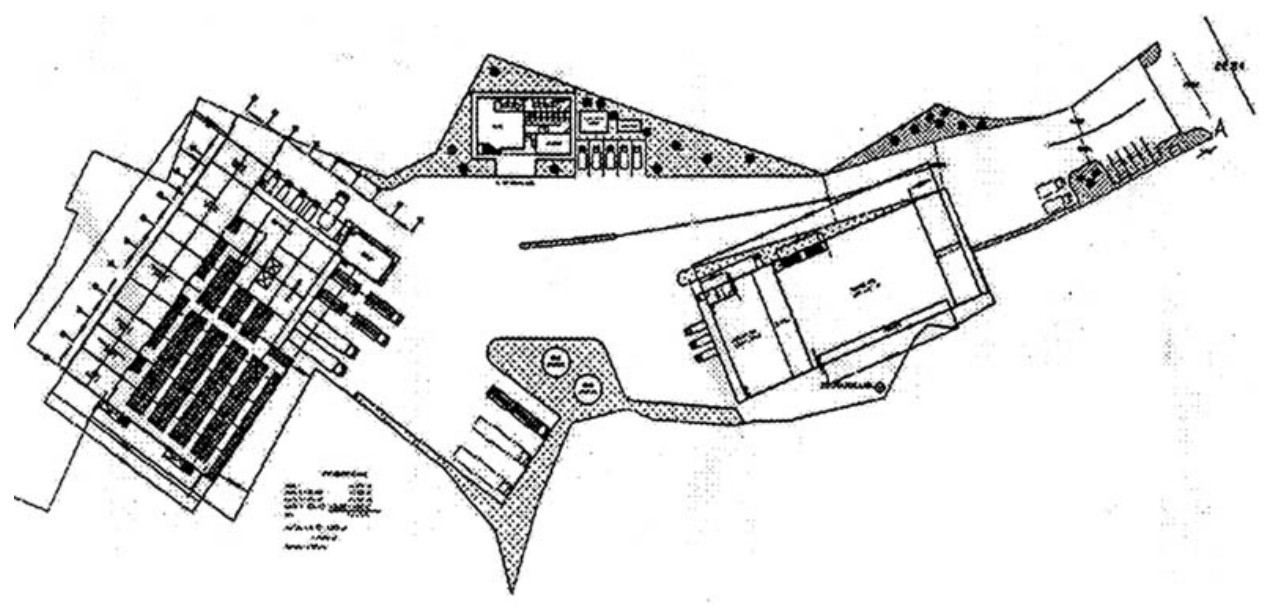

Gambar 4. Rencana pengembangan lahan.

\section{KETERSEDIAAN DAN KELAYAKAN DATA}

Untuk dapat mengukur potensi limpasan yang terjadi pada kawasan tersebut, serangkaian analisis yang dilakukan di dalam studi ini meliputi analisis kelayakan data curah hujan, analisis curah hujan rencana, analisis kurva IDF, dan analisis debit banjir. Analisis kelayakan data hujan yang dilakukan meliputi pemeriksaan adanya outlier, pemeriksaan adanya trend, pemeriksaan stabilitas variance dan mean, dan pemeriksaan adanya independensi. 
Berdasarkan hasil analisis kelayakan data hujan yang diperoleh dari Stasiun Badan Meteorologi dan Geofisika (BMG), Bandung untuk periode tahun 1986-2000 diketahui bahwa pada 3 buah durasi hujan terdapat outlier pada seri data. Hasil selengkapnya disajikan pada Tabel 2 berikut ini.

Tabel 2. Hasil uji kelayakan data hujan.

\begin{tabular}{cccccc}
\hline \multirow{2}{*}{$\begin{array}{c}\text { Curah Hujan } \\
\text { (menit) }\end{array}$} & Outliers & Trend & \multicolumn{2}{c}{ Stabilitas } & Independensi \\
\cline { 4 - 5 } & Varians & Mean & \\
\hline 5 & tidak ada & tidak ada & stabil & stabil & independen \\
10 & ada & tidak ada & stabil & stabil & independen \\
15 & tidak ada & tidak ada & stabil & stabil & independen \\
20 & tidak ada & tidak ada & stabil & stabil & independen \\
45 & ada & tidak ada & stabil & stabil & independen \\
60 & ada & tidak ada & stabil & stabil & independen \\
120 & ada & tidak ada & stabil & stabil & independen \\
180 & ada & tidak ada & stabil & stabil & independen \\
360 & ada & tidak ada & stabil & stabil & independen \\
720 & ada & tidak ada & stabil & stabil & independen \\
\hline
\end{tabular}

\section{ANALISIS CURAH HUJAN RENCANA}

Seperti halnya analisis kelayakan data hujan yang meliputi beberapa tahap analisis, pada analisis frekuensi selain mengestimasi besarnya curah hujan rencana, dilakukan pula penentuan distribusi probabilitas curah hujan. Dua buah metode yang umumnya digunakan untuk menentukan kesesuaian distribusi probabilitas adalah metode Chi Kuadrat dan metode Kolomogorov-Smirnov. Namun karena metode Chi-Kuadrat hanya efektif bila jumlah data pengamatan besar, maka di dalam studi ini penentuan distribusi probabilitas curah hujan dilakukan dengan menggunakan metode Kolmogorov-Smirnov.

Berdasarkan hasil uji metode Kolmogorov-Smirnov, diketahui bahwa semua jenis distribusi probabilitas memenuhi syarat. Secara umum, distribusi probabilitas yang memberikan nilai penyimpangan terkecil adalah bervariasi untuk berbagai jenis durasi hujan. Namun karena distribusi Pearson-III mendominasi jumlah distribusi probabilitas yang memberikan nilai penyimpangan terkecil dan memiliki nilai curah hujan rencana yang relatif sama besar dibandingkan distribusi log normal 2 parameter dan log Pearson III, maka dalam analisis selanjutnya curah hujan rencana digunakan adalah curah hujan berdasarkan distribusi Pearson-III. Hasil perhitungan besarnya curah hujan rencana berdasarkan distribusi Pearson III disajikan pada Tabel 3.

Pemanfaatan Kolam Retensi Dan Sumur Resapan Pada Sistem Drainase Kawasan Padat Penduduk (Doddy Yudianto, Andreas F. V. Roy) 
Tabel 3. Curah hujan rencana untuk masing-masing durasi hujan berdasarkan distribusi probabilitas Pearson III (satuan dalam mm.)

\begin{tabular}{|c|c|c|c|c|c|c|c|c|c|c|}
\hline \multicolumn{11}{|c|}{ Periode } \\
\hline Ulang & 5 & 10 & 15 & 20 & 45 & 60 & 120 & 180 & 360 & 720 \\
\hline 2 & 13,17 & 19,86 & 25,17 & 35,43 & 45,82 & 48,77 & 55,80 & 58,50 & 65,99 & 71,18 \\
\hline 5 & 16,60 & 22,47 & 29,81 & 41,06 & 51,05 & 53,79 & 60,49 & 66,04 & 77,61 & 80,91 \\
\hline 10 & 18,60 & 23,90 & 32,19 & 43,73 & 53,92 & 56,61 & 62,89 & 70,43 & 84,48 & 86,54 \\
\hline 20 & 20,36 & 25,12 & 34,14 & 45,80 & 56,36 & 59,04 & 64,85 & 74,29 & 90,60 & 91,48 \\
\hline 25 & 20,90 & 25,48 & 34,70 & 46,38 & 57,08 & 59,76 & 65,41 & 75,46 & 92,45 & 92,97 \\
\hline 50 & 22,47 & 26,52 & 36,31 & 47,98 & 59,18 & 61,89 & 67,02 & 78,90 & 97,97 & 97,36 \\
\hline 100 & 23,95 & 27,48 & 37,74 & 49,36 & 61,10 & 63,86 & 68,46 & 82,14 & 103,18 & 101,47 \\
\hline 1000 & 28,44 & 30,26 & 41,70 & 52,88 & 66,68 & 69,68 & 72,42 & 91,93 & 119,12 & 113,86 \\
\hline
\end{tabular}

\section{ANALISIS KURVA IDF}

Dengan luas daerah studi yang kecil, maka di dalam studi ini besarnya debit banjir ditentukan berdasarkan metode rasional. Untuk itu di dalam studi ini pula dilakukan analisis kurva IDF berdasarkan persamaan Talbot, persamaan Sherman, dan persamaan Ishiguro. Kurva ini umumnya dimanfaatkan untuk hujan dengan durasi pendek berkisar dari 5 menit sampai dengan beberapa jam.

Berdasarkan hasil analisis kurva IDF dari ketiga persamaan tersebut di atas, diketahui bahwa distribusi seri data hujan BMG Bandung mengikuti metode Talbot. Secara grafis hasil perbandingan ketiga metode dapat dilihat pada Gambar 5. Dengan demikian, kurva IDF untuk seri data hujan BMG Bandung yang akan digunakan pada tahap analisis debit banjir ditentukan berdasarkan metode Talbot. Untuk kurva IDF pada periode ulang 2, 10, dan 25 tahun secara jelas disajikan pada Gambar 6.



Gambar 5. Kurva IDF untuk metode Talbot, Sherman, dan Ishiguro. 




Gambar 6. Kurva IDF berdasarkan metode Talbot.

\section{ANALISIS DEBIT BANJIR}

Analisis debit banjir dilakukan untuk mengetahui besar debit aliran rencana yang mungkin terjadi sesuai dengan periode ulang tertentu. Besarnya debit banjir tersebut diperlukan sebagai dasar perencanaan hidraulik sistem drainase beserta bangunan pelengkapnya. Untuk kawasan permukiman dan perkotaan, perencanaan sistem drainase didasarkan pada debit banjir dengan periode ulang 10 tahun. Secara matematis metode rasional dinyatakan sebagai berikut:

$$
Q=0,278 \times C \times I \times A \quad\left(\mathrm{~m}^{3} / \text { detik }\right)
$$

dengan:

$\mathrm{Q} \quad=$ debit banjir maksimum $\left(\mathrm{m}^{3} /\right.$ detik$)$

C = koefisien pengaliran/limpasan, tergantung kondisi lahan untuk jenis lahan industri ringan, besarnya koefisien $\mathrm{C}=0,8$ [Akan, 1993]

I = intensitas hujan rencana dengan durasi sama dengan waktu konsentrasi $(\mathrm{mm} / \mathrm{jam})$

A $\quad=$ luas daerah pengaliran $\left(\mathrm{km}^{2}\right)$

Intensitas hujan merupakan fungsi dari durasi hujan dan waktu konsentrasi. Besarnya intensitas ditentukan menggunakan kurva IDF berdasarkan periode ulang hujan dan lama waktu pengaliran. Secara umum, total lama waktu pengaliran adalah hasil penjumlahan terbesar antara waktu aliran di atas permukaan lahan dan waktu aliran pada saluran dengan titik acuan yang sama. Dengan memperhitungkan besarnya pengaruh jenis 
lapisan penutup lahan, besarnya waktu aliran limpasan di atas lahan dapat dihitung dengan persamaan Hathway berikut:

$$
t_{o}=\frac{1,44(L \cdot n)^{0,476}}{S^{0,234}}
$$

dengan:

$\mathrm{t}_{\mathrm{o}} \quad=$ waktu pengaliran di lahan (menit)

$\mathrm{L} \quad=$ panjang overland flow $(\mathrm{m})$

$\mathrm{n} \quad=$ koefisien penutup lahan, untuk perkerasan halus $\mathrm{n}=0,02$ [Ponce, 1989]

$\mathrm{S} \quad=$ kemiringan lahan

Sedangkan lamanya waktu pengaliran di sepanjang saluran dapat dihitung dengan menggunakan persamaan rasional sebagai berikut:

$$
t_{d}=\frac{L s}{60 \cdot v}
$$

dengan:

td $\quad=$ waktu pengaliran di saluran (menit)

Ls = panjang saluran $(\mathrm{m})$

$\mathrm{v} \quad=$ kecepatan aliran $(\mathrm{m} / \mathrm{dt})$

Sesuai dengan rencana pengembangan lokasi studi, lahan direncanakan dengan kemiringan sebesar $1 \%$ terhadap sistem drainase yang terdapat pada sisi kiri dan kanan lahan. Berdasarkan lay out skema sistem drainase yang dapat dilihat pada Gambar 7, besarnya debit banjir dengan periode ulang 10 tahun dan dimensi saluran untuk masingmasing ruas saluran pada lahan dapat dilihat pada Tabel 4 dan Tabel 5.

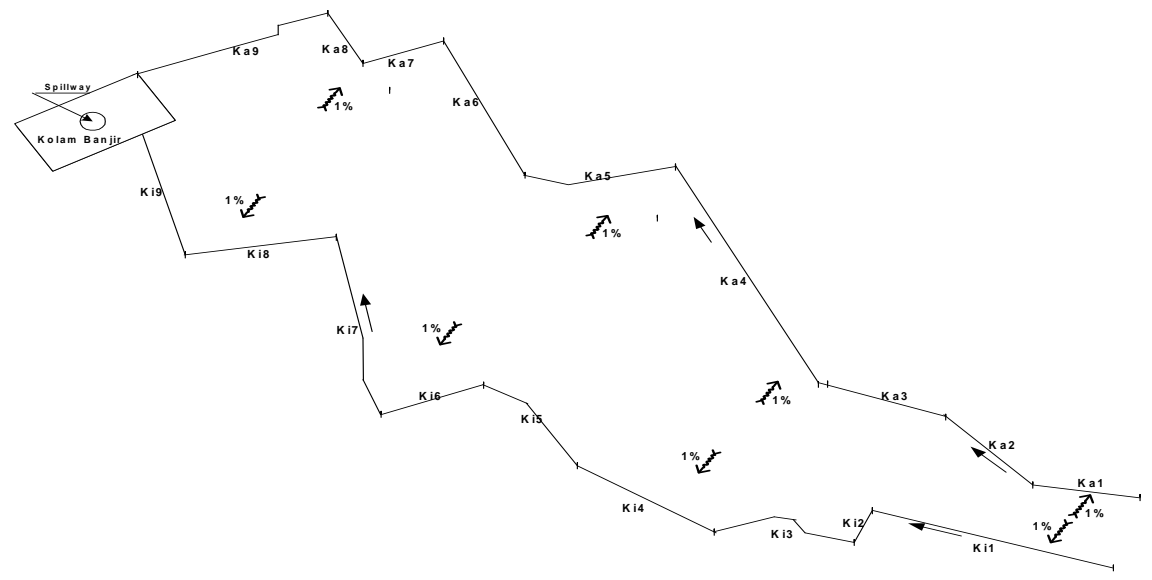

Gambar 7. Lay out sistem drainase lahan. 
Tabel 4. Debit banjir dan dimensi saluran drainase kiri.

\begin{tabular}{|c|c|c|c|c|c|c|c|c|c|c|c|c|c|}
\hline \multirow{2}{*}{ No. } & \multirow{2}{*}{$\begin{array}{l}\text { Ruas } \\
\text { Saluran }\end{array}$} & \multirow{2}{*}{$\begin{array}{l}\text { Panjang } \\
\text { Saluran } \\
\text { (m) }\end{array}$} & \multirow{2}{*}{$\begin{array}{l}\text { Slope } \\
\text { Saluran }\end{array}$} & \multirow{2}{*}{$\begin{array}{c}\text { Koef. } \\
\text { Manning }\end{array}$} & \multirow{2}{*}{ tc } & \multirow{2}{*}{1} & \multirow{2}{*}{$Q_{\text {final }}$} & \multirow{2}{*}{$Y n(m)$} & \multirow{2}{*}{ Yc (m) } & \multirow{2}{*}{ Ket. } & \multirow{2}{*}{$\begin{array}{c}\mathrm{V} \\
\text { (m/det) }\end{array}$} & \multicolumn{2}{|c|}{ Dimensi Saluran } \\
\hline & & & & & & & & & & & & $\mathrm{B}(\mathrm{cm})$ & $(\mathrm{H}(\mathrm{cm})$ \\
\hline 1 & 2 & 3 & 4 & 5 & 6 & 7 & 8 & 9 & 10 & 11 & 12 & 13 & 14 \\
\hline 1 & Ki1 & 34,000 & 0,005 & 0,025 & 2,186 & 204,644 & 0,042 & 0,150 & 0,090 & Subkritis & 0,577 & 50 & 40 \\
\hline 2 & $\mathrm{Ki} 2$ & 7,000 & 0,005 & 0,025 & 2,323 & 196,033 & 0,053 & 0,170 & 0,100 & Subkritis & 0,617 & 50 & 40 \\
\hline 3 & Кi3 & 21,000 & 0,005 & 0,025 & 3,569 & 192,634 & 0,073 & 0,220 & 0,130 & Subkritis & 0,673 & 50 & 40 \\
\hline 4 & $\mathrm{Ki} 4$ & 21,000 & 0,005 & 0,025 & 3,978 & 199,212 & 0,098 & 0,270 & 0,160 & Subkritis & 0,725 & 50 & 50 \\
\hline 5 & Ki5 & 20,000 & 0,005 & 0,025 & 4,367 & 186,325 & 0,114 & 0,300 & 0,170 & Subkritis & 0,752 & 50 & 50 \\
\hline 6 & Ki6 & 15,000 & 0,005 & 0,025 & 4,659 & 184,120 & 0,133 & 0,340 & 0,190 & Subkritis & 0,778 & 50 & 50 \\
\hline 7 & $\mathrm{Ki} 7$ & 32,500 & 0,005 & 0,025 & 5,291 & 179,515 & 0,160 & 0,390 & 0,220 & Subkritis & 0,809 & 50 & 60 \\
\hline 8 & Ki8 & 20,000 & 0,005 & 0,025 & 5,680 & 176,794 & 0,173 & 0,420 & 0,230 & Subkritis & 0,822 & 50 & 60 \\
\hline 9 & Ki9 & 21,000 & 0,005 & 0,025 & 6,089 & 174,024 & 0,202 & 0,480 & 0,260 & Subkritis & 0,848 & 50 & 70 \\
\hline
\end{tabular}

Tabel 5. Debit banjir dan dimensi saluran kiri.

\begin{tabular}{|c|c|c|c|c|c|c|c|c|c|c|c|c|c|}
\hline \multirow{2}{*}{ No. } & \multirow{2}{*}{$\begin{array}{c}\text { Ruas } \\
\text { Saluran }\end{array}$} & \multirow{2}{*}{$\begin{array}{l}\text { Panjang } \\
\text { Saluran } \\
\text { (m) }\end{array}$} & \multirow{2}{*}{$\begin{array}{l}\text { Slope } \\
\text { Saluran }\end{array}$} & \multirow{2}{*}{$\begin{array}{c}\text { Koef. } \\
\text { Manning }\end{array}$} & \multirow{2}{*}{ tc } & \multirow{2}{*}{1} & \multirow{2}{*}{$Q_{\text {final }}$} & \multirow{2}{*}{$\mathrm{Yn}(\mathrm{m})$} & \multirow{2}{*}{$\mathrm{Yc}(\mathrm{m})$} & \multirow{2}{*}{ Ket. } & \multirow{2}{*}{$\underset{\text { (m/det) }}{V}$} & \multicolumn{2}{|c|}{ Dimensi Saluran } \\
\hline & & & & & & & & & & & & $\mathrm{B}(\mathrm{cm})$ & $(\mathrm{H}(\mathrm{cm})$ \\
\hline 1 & 2 & 3 & 4 & 5 & 6 & 7 & 8 & 9 & 10 & 11 & 12 & 13 & 14 \\
\hline 1 & Ka1 & 20,000 & 0,005 & 0,025 & 1,914 & 207,188 & 0,034 & 0,120 & 0,080 & Subkritis & 0,541 & 50 & 40 \\
\hline 2 & $\mathrm{Ka} 2$ & 17,500 & 0,005 & 0,025 & 2,255 & 204,017 & 0,050 & 0,160 & 0,100 & Subkritis & 0,607 & 50 & 40 \\
\hline 3 & Ka3 & 20,000 & 0,005 & 0,025 & 2,644 & 200,510 & 0,063 & 0,190 & 0,120 & Subkritis & 0,648 & 50 & 40 \\
\hline 4 & $\mathrm{Ka} 4$ & 42,500 & 0,005 & 0,025 & 3,471 & 190,355 & 0,123 & 0,320 & 0,180 & Subkritis & 0,765 & 50 & 50 \\
\hline 5 & Ka5 & 22,500 & 0,005 & 0,025 & 4,289 & 186,923 & 0,141 & 0,360 & 0,200 & Subkritis & 0,788 & 50 & 60 \\
\hline 6 & $\mathrm{Ka} 6$ & 24,500 & 0,005 & 0,025 & 4,766 & 183,324 & 0,172 & 0,420 & 0,230 & Subkritis & 0,821 & 50 & 60 \\
\hline 7 & Ka7 & 11,000 & 0,005 & 0,025 & 4,980 & 181,753 & 0,178 & 0,430 & 0,230 & Subkritis & 0,827 & 50 & 60 \\
\hline 8 & Ka8 & 10,500 & 0,005 & 0,025 & 5,184 & 180,278 & 0,183 & 0,440 & 0,240 & Subkritis & 0,831 & 50 & 60 \\
\hline 9 & $\mathrm{Ka9}$ & 24,500 & 0,005 & 0,025 & 5,661 & 176,928 & 0,186 & 0,450 & 0,240 & Subkritis & 0,834 & 50 & 70 \\
\hline
\end{tabular}

Dengan asumsi besarnya limpasan air hujan di luar lahan yang diperhitungkan sebagai kontribusi tambahan terhadap beban sistem drainase lahan sebesar $0,01 \mathrm{~m}^{3} / \mathrm{dt}$, maka total besarnya debit banjir untuk saluran kiri adalah $0,202 \mathrm{~m}^{3} / \mathrm{dt}$ (tc $=6,1$ menit) dan saluran kanan adalah $0,186 \mathrm{~m}^{3} / \mathrm{dt}$ (tc $=5,7$ menit). Berdasarkan nilai perhitungan debit banjir yang diperoleh, maka besarnya dimensi saluran drainase batu kali dengan kemiringan dasar saluran 0,5\% dan tinggi jagaan sebesar 0,15 m untuk debit lebih kecil dari pada 1,5 m $/ \mathrm{dt}$ adalah bervariasi antara $0,5 \mathrm{~m} \times 0,4 \mathrm{~m}$ hingga $0,5 \mathrm{~m} \times 0,7 \mathrm{~m}$. Berdasarkan hasil analisis tersebut pula, diketahui bahwa secara umum jenis aliran yang ada pada saluran drainase adalah aliran subkritis dan kecepatan aliran pada seluruh ruas saluran lebih kecil dari pada kecepatan ijin yaitu $1,5 \mathrm{~m} / \mathrm{dt}$. 


\section{ANALISIS DEBIT SUMUR RESAPAN}

Berdasarkan skema sistem drainase pada Gambar 7, kolam tampungan dan sumur resapan direncanakan terletak pada sisi belakang lokasi studi. Merujuk kepada diagram alir perencanaan teknis sumur resapan yang tersaji pada Gambar 2, sumur resapan dapat dibangun jika kedalaman muka air tanah lebih atau sama dengan 3,0 m dan koefisien permebilitas lebih atau sama dengan 2,0 cm/jam.

Dari hasil penyelidikan geoteknik didapatkan bahwa pada kedalaman 7,5-20,0 m ditemukan lapisan tanah (akuifer) yang didominasi oleh pasir kasar bercampur sedikit lempung. Fakta ini diperkuat atas hasil survei yang dilakukan pada sumur bor-sumur bor yang dimiliki masyarakat sekitar. Kedalaman sumur bor-sumur bor yang dimiliki masyarakat sekitar berkisar antara 12,0-18,0 m dengan rata-rata jarak horizontal dari titik bor penyelidikan geoteknik antara 5,0-25,0 m.

Hasil temuan lain dari penyelidikan geoteknik adalah terdapatnya muka air tanah yang sangat dangkal pada lokasi pengeboran yaitu 0,5 m dari permukaan tanah. Dangkalnya muka air tanah ini terjadi karena adanya lapisan tanah yang kedap air antara kedalaman 1,0 0,5 m. Berdasarkan kondisi tersebut maka jenis sumur resapan yang akan dipilih dalam studi ini adalah sumur resapan dalam. Besarnya debit resapan menurut Suripin dapat dihitung dengan menggunakan persamaan berikut:

$$
Q=\frac{2 \pi \cdot K B H}{\ln \frac{B}{r}}
$$

dengan:

$\mathrm{Q}=\operatorname{debit}\left(\mathrm{m}^{3} /\right.$ detik$)$

$\mathrm{K}=$ permeabilitas akuifer (m/detik)

B = ketebalan lapisan akuifer $(\mathrm{m})$

$\mathrm{H} \quad=$ ketinggian potentiomentric surface

$\mathrm{r} \quad=$ jari-jari sumur resapan $(\mathrm{m})$

Mengacu kepada jenis tanah seperti tersaji pada Tabel 7, besar koefisien permebilitas untuk lapisan tersebut diperkirakan antara 4 x 10-3 sampai dengan 4 x 10-5 $\mathrm{m} / \mathrm{dt}$. Dengan tebal lapisan akuifer (B) setebal 12,5 meter, ketinggian potentiomentric surface $(\mathrm{H})$ adalah 0,5 meter dan jari-jari sumur resapan sebesar 1,25 m, maka berdasarkan hasil perhitungan di dapatkan besarnya debit resapan potensial adalah sebesar 0,007 $\mathrm{m}^{3} / \mathrm{dt}$. 
Tabel 7. Angka koefisien permeabilitas untuk berbagai jenis tanah dan material

(Carter, M. Dan Bentley, S.P., 1991)

\begin{tabular}{lc}
\hline \multicolumn{1}{c}{ Material } & Permeability (m/s) \\
\hline Uniformly graded coarse aggregate & $0,4-4 \times 10^{-3}$ \\
Well-graded aggregate without fines & $4 \times 10^{-3}-4 \times 10^{-5}$ \\
Concrete sand, low dust content & $7 \times 10^{-4}-7 \times 10^{-6}$ \\
Concrete sand, high dust content & $7 \times 10^{-6}-7 \times 10^{-8}$ \\
Silty and clayey sands & $10^{-7}-10^{-9}$ \\
Compacted silt & $7 \times 10^{-8}-7 \times 10^{-10}$ \\
Compacted clay & less than $10^{-9}$ \\
Bituminous concrete & $4 \times 10^{-5}-4 \times 10^{-8}$ \\
Portland cement concrete & less than $10^{-10}$ \\
\hline
\end{tabular}

Sesuai dengan kondisi pelapisan tanah pada lokasi studi, maka sumur resapan direncanakan dengan kedalaman 10,0 m dengan tinggi susunan batu kali pada dasar sumur adalah 1,0 m. Dengan demikian, besar volume awal yang memenuhi ruang sumur dan kemudian meresap secara perlahan meresap adalah 44,2 $\mathrm{m}^{3}$. Volume air yang dapat ditampung di dalam sumur ini secara tidak langsung berfungsi sebagai volume pengurang terhadap volume limpasan yang masuk ke dalam kolam tampungan.

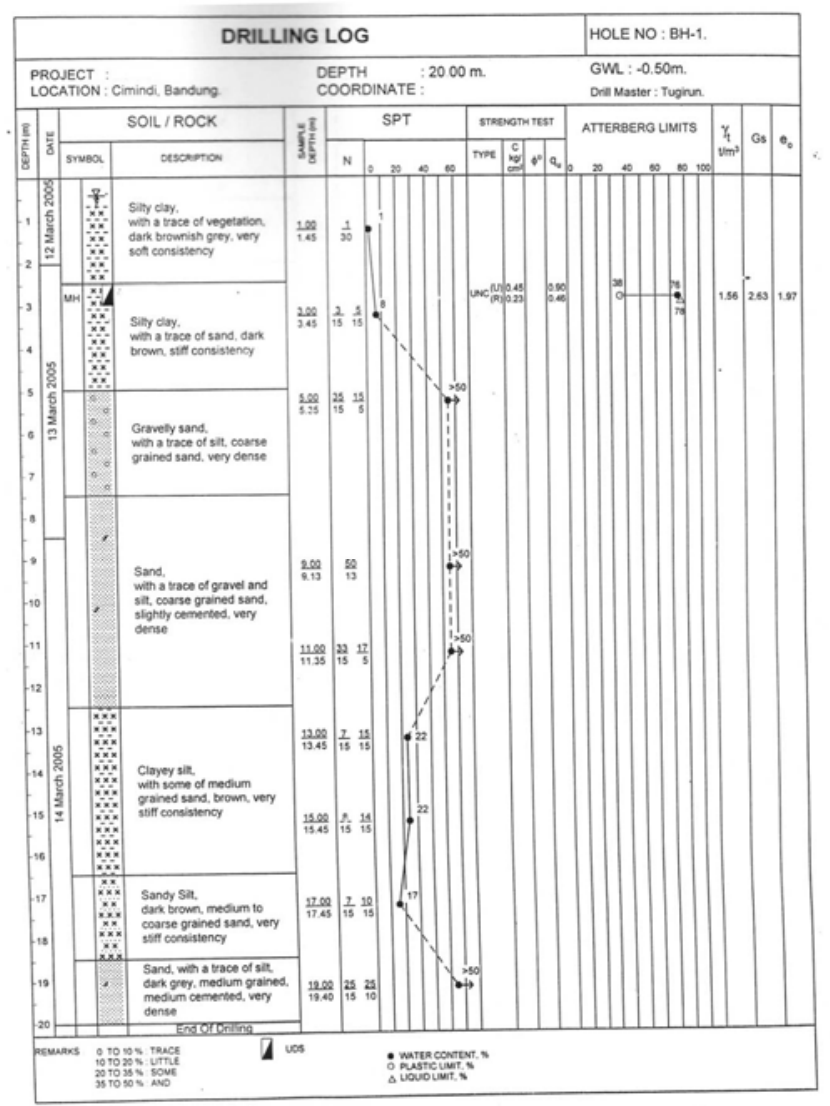

Gambar 8. Borlog Hasil Penyelidikan Geoteknik.

Pemanfaatan Kolam Retensi Dan Sumur Resapan Pada Sistem Drainase Kawasan Padat Penduduk (Doddy Yudianto, Andreas F. V. Roy) 


\section{PERENCANAAN KOLAM RETENSI}

Dimensi kolam retensi dapat ditentukan dengan melakukan penelusuran banjir berdasarkan metode Muskingum reservoir routing. Hidrograf banjir aliran masuk untuk perencanaan kolam retensi berasal dari kedua sisi saluran drainase. Sumur resapan direncanakan terletak di tengah kolam retensi yang memiliki tinggi awal genangan sebesar 0,3 m sebagai fasilitas air cadangan untuk kebutuhan cuci dan sebagainya. Secara jelas, sketsa layout kolam retensi yang direncanakan disajikan pada Gambar 9.

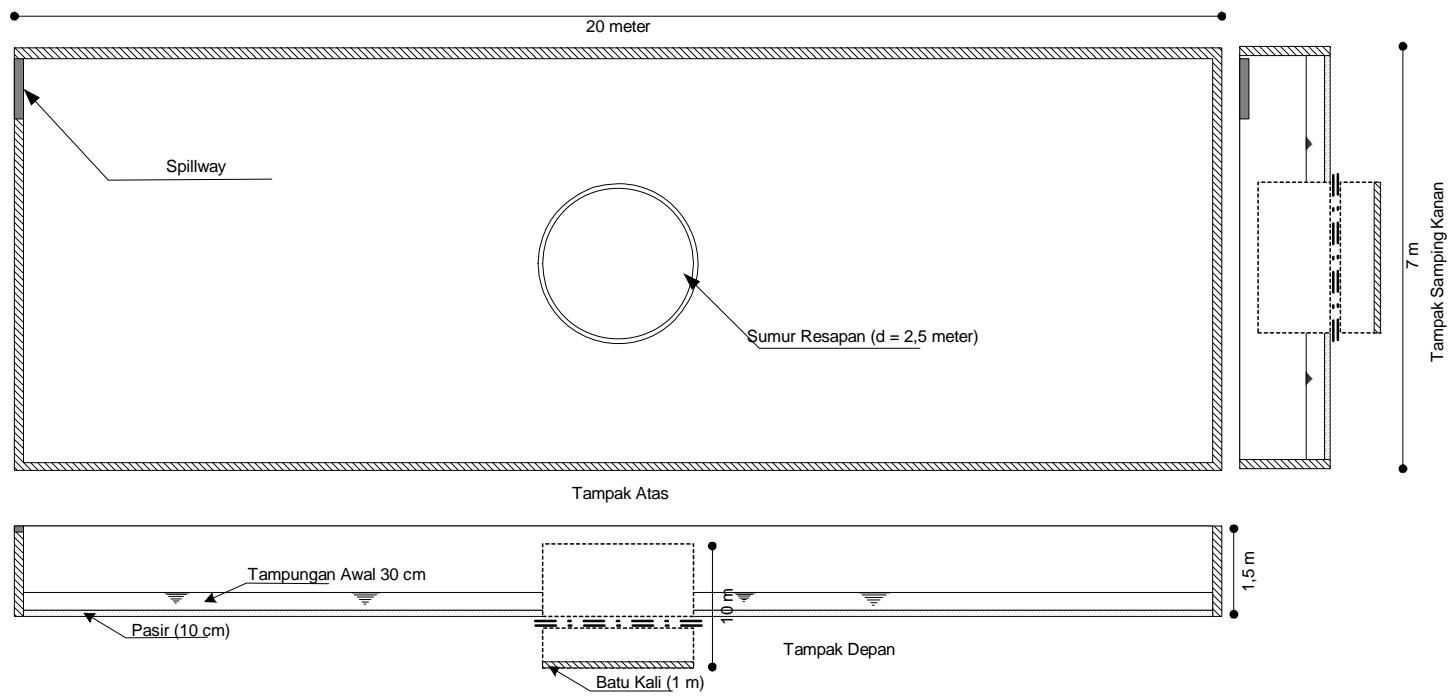

Gambar 9. Sketsa layout kolam retensi dan sumur resapan.

Dengan diketahuinya debit sumur resapan sebesar 0,007 $\mathrm{m}^{3} /$ detik, berdasarkan hasil penelusuran banjir reservoir diketahui bahwa volume kolam retensi minimum yang diperlukan untuk kebutuhan pengendalian banjir pada lahan gudang adalah $169 \mathrm{~m}^{3}$. Hasil perhitungan selengkapnya dapat dilihat pada Tabel 8 dan Gambar 10.

Tabel 8. Hubungan antara Qsumur resapan, elevasi muka air maksimum dan volume genangan.

\begin{tabular}{ccccc}
\hline $\begin{array}{c}\mathrm{Q}_{\text {sumur }} \\
\left(\mathrm{m}^{3} / \mathrm{dt}\right)\end{array}$ & $\begin{array}{c}\text { Tinggi Muka Air di } \\
\text { Atas Sumur } \\
(\mathrm{m})\end{array}$ & $\begin{array}{c}\text { Volume Genangan } \\
\text { Kolam } \\
\left(\times 1000 \mathrm{~m}^{3}\right)\end{array}$ & $\begin{array}{c}\text { Awal Pengisian Sumur } \\
(\text { menit ke- })\end{array}$ & $\begin{array}{c}\text { Waktu Puncak } \mathrm{Q}_{\text {Sumur }} \\
\text { (menit ke-) }\end{array}$ \\
\hline 0,367 & 0,173 & 0,099 & 5,0 & 7,0 \\
0,227 & 0,126 & 0,137 & 7,0 & 9,0 \\
0,143 & 0,092 & 0,155 & 8,0 & 10,0 \\
0,007 & 0,012 & 0,169 & 11,0 & 12,0 \\
\hline
\end{tabular}

Catatan: elevasi dasar kolam di asumsikan pada $+0,00 \mathrm{~m}$ 
Merujuk lepada Tabel 8 dan Gambar 10 dapat disimpulkan bahwa untuk tinggi sumur resapan 1,2 m dengan tinggi jagaan kolam sebesar 0,3 m terdapat beberapa alternatif pilihan untuk dimensi kolam retensi. Namun sesuai dengan kondisi lahan yang tersedia, maka alternatif dimensi dimensi kolam retensi yang paling sesuai adalah 7,0 m x 20,0 m x 1,5 m. Untuk mengatasi debit banjir di atas periode ulang 10 tahun, diperlukan penempatan sebuah pelimpah dengan lebar 1,0 m pada kolam dengan elevasi puncak pelimpah adalah $0,17 \mathrm{~m}$ di atas elevasi bibir sumur resapan.



Gambar 10. Hubungan antara panjang, lebar dan tinggi sumur resapan.

\section{KESIMPULAN DAN SARAN}

Berdasarkan serangkaian analisis yang telah dilakukan dapat ditarik beberapa kesimpulan sebagai berikut:

1. Saluran drainase saat ini dengan dimensi $0,2 \mathrm{~m} \times 0,2 \mathrm{~m}$ tidak lagi memadai untuk menerima beban limpasan hujan pada area gudang yang dikembangkan sebagai lahan kedap air. Hasil analisis menunjukkan bahwa dimensi saluran drainase yang diperlukan bervariasi antara 0,5 m (lebar) x 0,4 m (tinggi) pada bagian hulu sistem saluran hingga 0,5 m (lebar) x 0,7 m (tinggi) pada bagian hilir sistem saluran.

2. Berdasarkan hasil simulasi penelusuran banjir reservoir, besarnya volume kolam retensi yang diperlukan untuk menerima beban drainase dengan periode ulang 10 tahun akibat perubahan tata guna lahan adalah $169 \mathrm{~m}^{3}$. Dengan direncanakannya sumur resapan setinggi 1,2 m dari dasar kolam, maka dimensi kolam retensi yang sesuai dengan 
ketersediaan lahan adalah 7,0 m x 20,0 m x 1,5 m.

3. Dengan dimensi kolam 7,0 $\mathrm{m} \times 20,0 \mathrm{~m} \times 1,5 \mathrm{~m}$, besarnya debit sumur resapan dengan diameter 1,25 m maksimum mencapai 7 liter/detik dengan ketinggian muka air di atas bibir sumur sekitar 0,012 m.

4. Untuk mengatasi debit banjir di atas periode ulang 10 tahun, diperlukan sebuah pelimpah dengan lebar 1,0 m pada kolam dengan elevasi puncak pelimpah adalah $0,17 \mathrm{~m}$ di atas elevasi bibir sumur resapan.

5. Pemanfaatan secara kombinasi antara kolam retensi dan sumur resapan pada lokasi studi menunjukan bahwa konsep sistem drainase yang berkelanjutan tetap dapat diterapkan pada kawasan padat penduduk, meskipun terdapat kemungkinan diperlukan biaya yang cukup besar.

6. Untuk menjamin sistem kolam retensi dan sumur resapan ini terus beroperasi dengan baik dan berkelanjutan, maka pihak-pihak yang terkait dan berkepentingan harus pula memperhatikan aspek-aspek lainnya, contohnya seperti aspek pembiayaan dan aspek pemeliharaan.

\section{DAFTAR PUSTAKA}

1. Akan, A.S. and Houghtlaen, R.J. (2003), Urban Hydrology, Hydraulics, and Stormwater Quality, John Wiley and Sons Inc., Englewood Cliffs, New Jersey.

2. Akan, A.S. (1993), Urban Stormwater Hydrology-A Guide to Engineering Calculation, Technomic Publishing, Pennsylvania.

3. Carter, M. and Bentley, S.P. (1991), Correlations of Soil Properties, Pentech Press, London.

4. Davis, Thomas. (2004), What is Sustainable Development, (online), (http://www.menominee.edu/sdi/whatis.htm, diakses 17 Juli 2004).

5. Johnston Smith Consulting Ltd. (2006), Sustainable Urban Drainage Systems, (online), (http://www.johnstonsmith.co.uk/fact15.html, diakses 7 September 2006).

6. McCuen, R.H. (1998), Hydrologic Analysis and Design, Prentice Hall, Englewood Cliffs, New Jersey, 1998.

7. Ponce, V.M. (1989), Engineering Hydrology-Principles and Practices, Prentice Hall. Inc., Englewood Cliffs, New Jersey.

8. Suripin. (2004), Sistem Drainase Perkotaan yang Berkelanjutan, Penerbit Andi, Yogyakarta. 
9. Sustainable Water Environment in Lancashire (SWEL). (2006), Sustainable Drainage Systems, (online), (http://www.swel.org.uk/suds.htm, diakses 6 September 2006).

10. United Nations, General Assembly. (2004), Report of The United Nations Conference On Environment and Development - Annex I - Rio Declaration On Environment and Development, (online), (http://www.un.org/documents/ga/conf151/aconf15126-1annex1.htm, diakses 17 Juli 2004).

11. Google Maps, (online), (http://maps.google.com/, diakses 13 Januari 2009).

12. DTI Global Watch Mission. (2006), Techinal Report, Sustainable Drainage System: a mission to the USA, Bistish Water.

13. Stahre P. (2005), 15 Years Experiences of Sustainable Urban Storm Drainage in the City of Malmo, Sweden, World Water and Environmental Resources Congress 2005 173, 154.

14. Spillett, P.B, Evans, S.G., Colquhoun, K., (2005), International Perspective on BMPS/SUDS: UK-Sustainable Stormwater Management in The UK, World Water and Environmental Resources Congress 2005 173, 196.

15. Andoh, R.Y.G., dan Iwugo K.O., (2002), Sustainable Urban Drainage Systems - A UK Perspective, Urban Drainage 2002 112, 19

16. Transport Directore-Directorate for the Build Environment, (2009), Designing Streets: Consultation Draft, The Scottish Government Publications, (online), (http://www.scotland.gov.uk/Publications/2009/01/27140909/10, diakses 11 Mei 2009). 